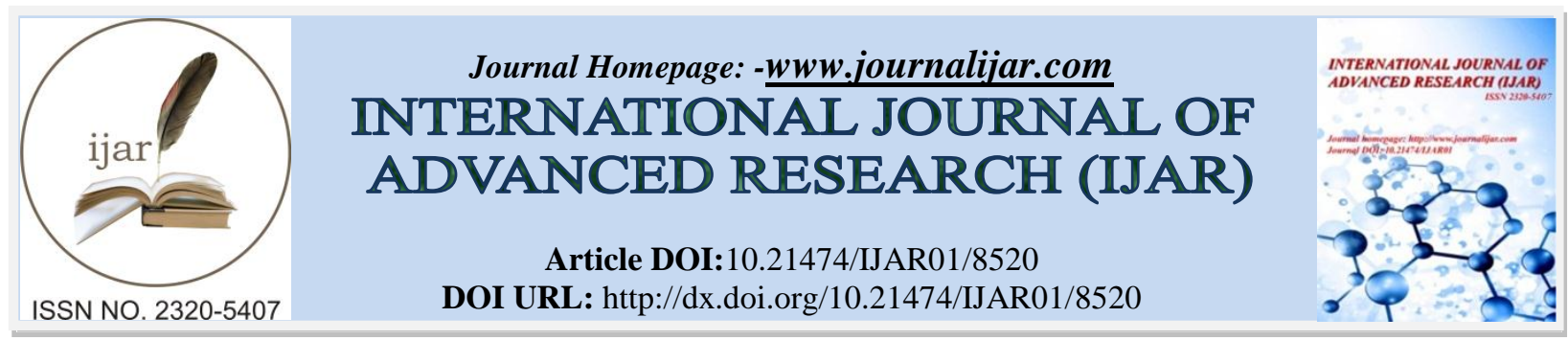

RESEARCH ARTICLE

\title{
EVALUATION OF EFFECT OF CATECHU PASTE FROM ACACIA CATECHU ON ORAL MICROFLORA.
}

\author{
Rachna Pandey. \\ Department of Botany and Microbiology, Govt. M.H. College of Home Science and Science for Women, Jabalpur \\ 482001 (MP) India.
}

\section{Manuscript Info}

Manuscript History

Received: 06 December 2018

Final Accepted: 08 January 2019

Published: February 2019

\section{Abstract}

Catechu, obtained from Acacia catechu heartwood is one of the important constituent of Paan, in which it is used as an astringent. The present study investigated in vitro the effect of various concentrations of catechu on oral microflora. The effect on prominent oral pathogenic bacteria, Enterococcus faecalis, Streptococcus mutans and yeast, Candida albicans was studied. The saliva samples, before and after the use of catechu were taken and the microorganisms were counted on plate count agar. The results showed significant decrease in the CFU count per $\mathrm{ml}$ of saliva and the population of the pathogenic bacteria also reduced significantly. The results showed that catechu was effective on oral pathogens and hence it can be stipulated that chewing of pan with catechu may be useful to maintain oral health.

Copy Right, IJAR, 2019,. All rights reserved.

\section{Introduction:-}

The Indian subcontinent is known for its rich culture and food habits. One of these traditional habits is using the paan, catechu, betle nuts etc as mouth freshners as well as for oral hygiene ${ }^{1}$. "Paan" is one of these psychoactive preparation, which use pan leaves (The betel leaf; Piper betle), alongwith kattha (a thich paste of catechu) alongwith areca nuts. Chewing of pan is one of the most important chewing habits in South East Asia including India, because of its stimulating and freshening properties. The paan is invariably used alongwith the catechu solution to give a soothing taste, as catechu has astringent properties ${ }^{2}$. Studies have shown that betel leaves (paan) is useful in maintaining oral hygiene ${ }^{3}$. However, no study has been performed on effect of catechu on oral pathogenic bacteria.

Catechu (Kattha in Hindi) is obtained from the heartwood of the Acacia catechu tree, which is found in abundance in Central India ${ }^{2}$. The decoction of the heartwood chips is obtained and allowed to form a cake like consistency. This cake is used in paan. The catch is used widely in traditional medicine for sore throats and diarrhoea. The concentrated aqueous extract, known as cutch, is an astringent ${ }^{4}$. It is used widely in Ayurvedic system of medicine ${ }^{5}$.

Oral hygiene is one of the important features to maintain oral and dental health. The main threat to the oral hygiene is the pathogenic bacteria and yeasts that harbour the oral cavity. Among such pathogens, Enterococcus faecalis, Streptococcus mutans and Candida albicans, are such notorious pathogens that deteriorate the oral health. E. faecalis, the predominant human enterococcus, causes dental caries, endodontic infections, periodontitis, and periimplantitis ${ }^{6}$. The $S$. mutans is a potent initiator of dental caries, while $C$. albicans causes oral candidiasis in humans ${ }^{7}$. 
Since, chewing of paan is a habit where the extracts of paan and its ingredients are present in oral cavity for long time, it is obvious that there must be any interaction between these compounds and the oral microorganisms. Since, chewing of paan is traditionally thought to be useful in maintaining oral hygiene, the present investigation was drafted around it, to prove this hypothesis, whether catechu is helful in reducing the population of oral pathogens.

\section{Materials and Methods:- \\ Choice of patients}

Healthy individuals between the age of 25 to 40, having no history of chewing tobacco and/or paan were chosen for the study. The individuals with no signs and symptoms of the oral pathogenicity were chosen. The patients with oral pathogenicity, on antibiotic course, elderly patients or individuals with habit of chewing tobacco were excluded from the study. The study was conducted on 50 individuals.

\section{Preparation of catechu}

For preparing the thick paste of catechu, to be used with paan, the heartwood from the fully grown tree of Acacia catechu was obtained from the Dumna Nature Reserve, Jabalpur. The heartwood is cut into small chips and was boiled in water for 18 to $20 \mathrm{~h}$. The resultant solution was allowed to settle and the settled paste was used for the study. Fresh betel leaves (paan) were purchased from the local market.

\section{Collection of sample}

Individuals were sampled for saliva $(1 \mathrm{ml})$ by aspiration method. The individuals were then given the paan having catechu and were asked to chew it for $5 \mathrm{~min}$. The control groups were asked to chew the paan only (without catechu) and the positive control were those individuals who did not chew any of these. After $5 \mathrm{~min}, 1 \mathrm{ml}$ of saliva sample was again aspirated.

\section{Culture of microorganisms}

For total bacterial count, $100 \mu 1$ of saliva sample was inoculated on plate count agar (HiMedia, India). For culturing the E. faecalis and S. mutans, $100 \mu \mathrm{l}$ of saliva sample was plated onto Brain Heart Infusion agar (HiMedia, India) and for C. albicans, $100 \mu \mathrm{l}$ of saliva sample was plated onto Cysteine Lactose Electrolyte Deficient agar (CLED agar, HiMedia, India). The plates were incubated for $48 \mathrm{~h}$ at $35^{\circ} \mathrm{C}$. The colonies observed were counted using a colony counter (EI, India).

\section{Statistical analysis:-}

One way ANOVA was used to find the significant differences in colony count from control using Sigma Graph pad Prism $^{\circledR}$ software version 6.0.

\section{Results:-}

The study investigated the role of catechu extract on oral pathogens, when the paan is used in a traditional way in most part of the Indian subcontinent (Fig 1).

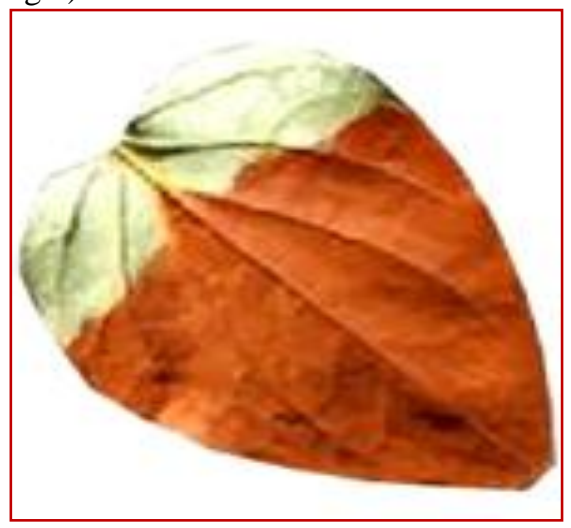

Fig 1:-Paan (betel) leaf with catchy paste, which is chewed in the traditional way in most part of India. 
For the study, 50 healthy individuals were asked to chew paan with catechu paste on to the leaf. The total plate count was noted before and after the paan chewing. Table 1 shows that the total plate count decreased significantly after the paan with catechu, while the plate count was not significantly reduced when either paan leaf was chewed or no treatment was given.

Table 1:-Mean total plate count of saliva samples taken before the start of treatment and after the treatment with or without catechu. Different superscript denote the significant difference from control $(n=50$, one way ANOVA, $p<0.05)$.

\begin{tabular}{|l|l|l|l|l|}
\hline S. No. & $\begin{array}{l}\text { Mean plate count } \\
\text { before treatment }\end{array}$ & $\begin{array}{l}\text { Mean plate count after 5 } \\
\text { min without treatment }\end{array}$ & $\begin{array}{l}\text { Mean plate count after } \\
5 \text { min of paan chewing } \\
\text { without catechu paste }\end{array}$ & $\begin{array}{l}\text { Mean plate count after 5 } \\
\text { min of paan chewing } \\
\text { with catechu paste }\end{array}$ \\
\hline 1. & $3.2 \times 10^{4} \pm 1.1 \times 10^{2 \mathrm{a}}$ & $3.4 \times 10^{4} \pm 1.4 \times 10^{2 \mathrm{a}}$ & $3.6 \times 10^{4} \pm 1.5 \times 10^{2 \mathrm{a}}$ & $1.3 \times 10^{3} \pm 1.1 \times 10^{1 \mathrm{~b}}$ \\
\hline
\end{tabular}

Table 2 shows that the growth of E. faecalis also reduced in cases where the paan leaf has catechu paste on it, in comparison to the saliva samples from those who chewed only paan leaf. In most of the cases, no growth on the brain heart infusion agar was observed, indicating that neither E. faecalis nor S. mutans were able to grow after the introduction of the catechu extract (Fig 2).

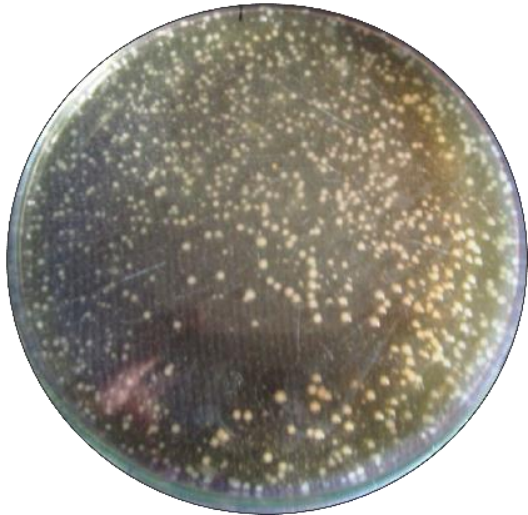

E. faecalis growth on BHI agar before treatment

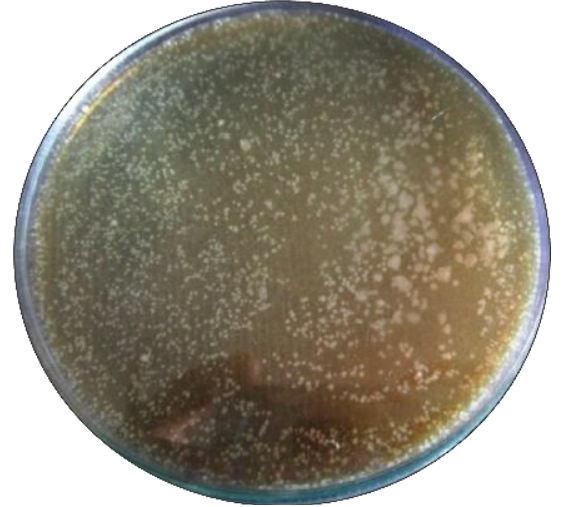

S. mutans growth on BHI agar before treatment

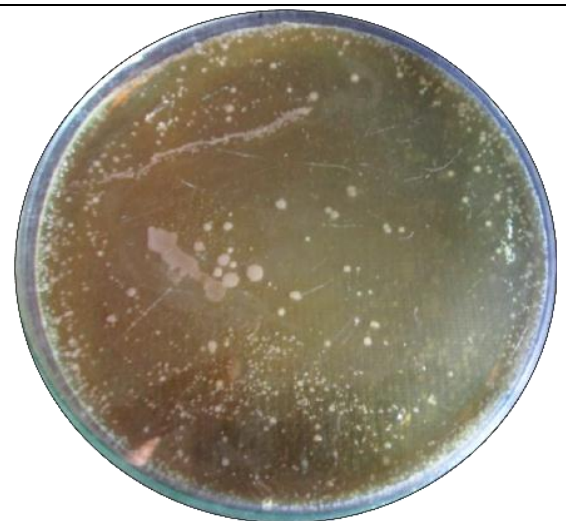

E. faecalis growth on BHI agar after treatment

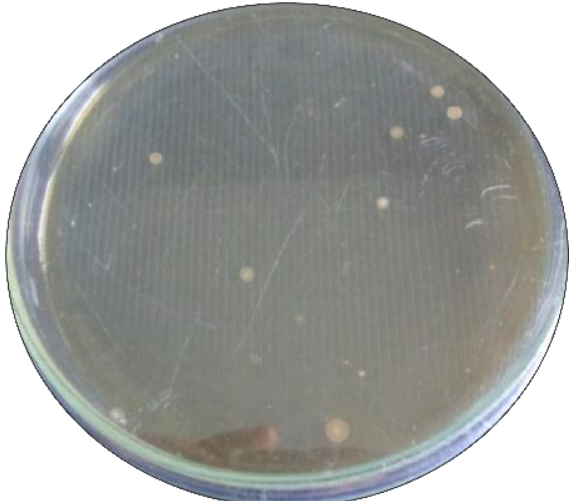

S. mutans growth on BHI agar after treatment 


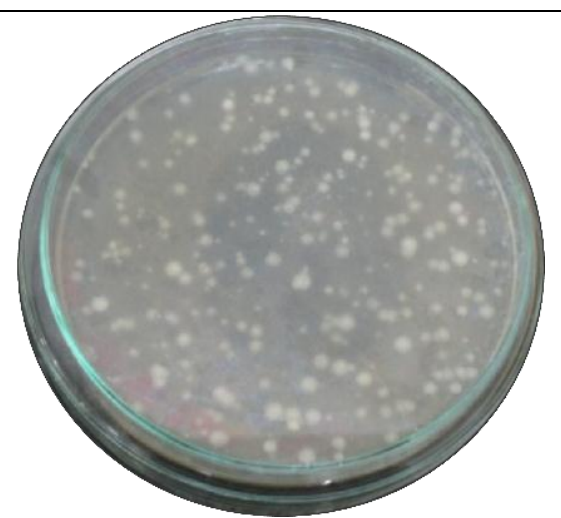

C. albicans growth on BHI agar before treatment

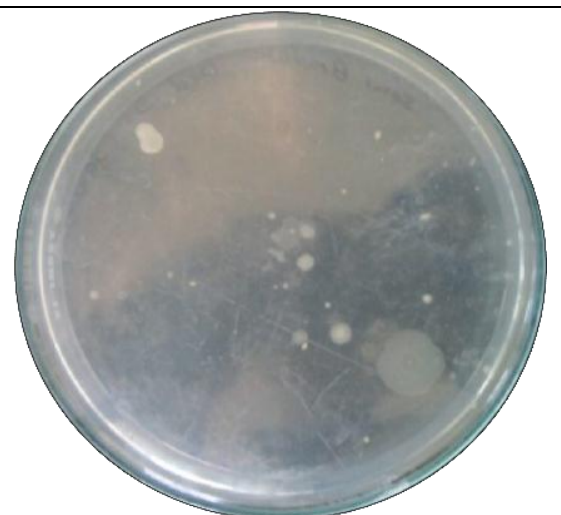

C. albicans growth on BHI agar before treatment

Fig 2:-Reduction of pathogenic bacterial count on specific agar media before and after using the catechu.

\section{Discussion:-}

The rich Indian culture and traditions have their roots in Ayurveda, which is a traditional system of medicine. Chewing of paan after the meals is one of those traditions, which still is alive in Indian subcontinent. The basic concept of chewing the traditional paan is to improve digestion as well as oral hygiene. Rare studies have been taken to see if catechu can work to reduce the oral pathogens in order to improve oral health.

Antimicrobial action of Acacia catechu has been studied by various workers. The methanolic extract of Acacia catechu was found to have antimicrobial activities against Bacillus subtilis, Staphylococcus aureus, Salmonella typhi, Escherichia coli, Pseudomonas aeruginosa and Candida albicans ${ }^{8}$. The extract of this plant is used to treat sore throats and as a mouthwash to combat gingivitis, dental and oral infections ${ }^{9}$. Although some studies have been able to show the reduction in bacterial count from oral cavity after chewing of paan, no study shows its effect on oral pathogenic bacteria ${ }^{10}$.

Chewing of paan is now not recommended by the dentists these days, because of the fact that paan is mostly served with areca nut as well as tobacco, which tend to have adverse effects on periodontal tissues and cause damage to oral mucosa ${ }^{9}$. Further, the tanning properties of catechu show discolouration of the teeth when used regularly. However, the role of catechu in maintaining oral health cannot be ruled out.

\section{References:-}

1. Verma, K.S. and Pandey, R., 2014. Antioxidant potential of young pods of Acacia catechu wild collected from Jabalpur region. Journal of pharmacognosy and phytochemistry, 2(6), pp.68-73.

2. Dasgupta, N. and De, B., 2004. Antioxidant activity of Piper betle L. leaf extract in vitro. Food chemistry, 88(2), pp.219-224.

3. Nalina, T. and Rahim, Z.H.A., 2007. The crude aqueous extract of Piper betle L. and its antibacterial effect towards Streptococcus mutans. Am J Biotechnol Biochem, 3(1), pp.10-15.

4. Pandey, R., 2016. Phenolic antioxidants from the roots of Acacia catechu from central India. World Journal Of Pharmacy And Pharmaceutical Sciences, 5(3), 1534-1542.

5. Verma, K.S., Pandey, R. and Ayachi, A., 2014. Nutritional assessment of different parts of Acacia catechu Willd. collected from central India. International Journal of Pharmaceutical Sciences and Research, 5(7), p.2980.

6. Ardizzoni, A., Pericolini, E., Paulone, S., Orsi, C.F., Castagnoli, A., Oliva, I., Strozzi, E. and Blasi, E., 2018. In vitro effects of commercial mouthwashes on several virulence traits of Candida albicans, viridans streptococci and Enterococcus faecalis colonizing the oral cavity. PloS one, 13(11), p.e0207262.

7. Banas, J.A. and Drake, D.R., 2018. Are the mutans streptococci still considered relevant to understanding the microbial etiology of dental caries?. BMC oral health, 18(1), p.129.

8. Negi, B.S. and Dave, B.P., 2010. In Vitro antimicrobial activity of Acacia catechu and its phytochemical analysis. Indian journal of microbiology, 50(4), pp.369-374.

9. Parmar, G., Sangwan, P., Vashi, P., Kulkarni, P. and Kumar, S., 2008. Effect of chewing a mixture of areca nut and tobacco on periodontal tissues and oral hygiene status. Journal of oral science, 50(1), pp.57-62.

10. Bissa, S., Songara, D. and Bohra, A., 2007. Traditions in oral hygiene: chewing of betel (Piper betle L.) leaves. Current Science, 92(1), pp.26-28. 